\title{
PAST CENTURIES INDUSTRIAL ARCHITECTURE RENOVATION METHODS
}

\author{
Tatiana ZHYDKOVA, Svetlana CHEPURNA, Olga POPOVA, Petr CHABANENKO
}

\begin{abstract}
The problems of exploitation of industrial territories located in big city centers and their impact on architectural and space urban composition have been investigated in the paper. The question of refurbishing former industrial territories to residential or social purposes has been examined. The examples of industrial territories use in other countries as well as in Kyiv and Kharkiv have been shown. The term loft has been defined in the article for industrial buildings converted to residential purpose by preserving industrial design elements or new buildings in an industrial style including those that combine residential function with professional or social.
\end{abstract}

Keywords: flour mill; "industrial" architecture landmarks; "industrial" enterprises; loft; physical conditions; renovation

\section{INTRODUCTION}

Industrial territories are one of the basic, system-forming elements in the structure of the city, shaping it as a socioeconomic development, as well as architectural and artistic appearance. Industrial and other production facilities built in cities are usually located far from the centers of urban settlements. But as the city grew, its economic and social functions expanded, most of the enterprises were in the historical center and the central planning area of the city. As a result, industrial buildings gradually became an important part of the architecture.

Refurbishment of industrial territories as well as reconstruction of separate industrial objects is not only an economic problem, but also an architectural one. Fundamental industrial buildings have significant impact on architectural appearance of the city. Unsatisfactory physical characteristics of urban environment objects and their functional incompatibility reduce social effectiveness of city centers requiring active professional interference, particularly into the process of spatial environment formation of historically valuable city spaces previously actively exploited. De-industrialization that became a global phenomenon in the middle of the last century can be fully observed in Ukraine nowadays. On the territory of the cities that were industrial centers in the previous centuries, today, you can find areas of land previously owned by former industrial enterprises. Although some areas have been already used for other purposes, most of them are still in town-planning reserve.

For former industrial objects, one of the most effective ways to move to a qualitatively new level is restructuring.

Such an economically grounded solution will save the structures of existing buildings, bring former industrial buildings in line with current international standards and preserve the unique architectural appearance of the building. In this case, the restructuring of such buildings is becoming an optimal means for the conversion of the existing base to the implementation of fundamentally new functions.

\section{THE MAIN STATEMENTS OF THE ARTICLE}

Special attention should be paid to the areas in city centers, as their location is a problem in itself. Former industrial territories are often neglected and if this problem is not paid due attention to, there is a risk of disappearance of unique objects of industrial architecture of the 19th century [8].

Most often industrial enterprises occupy large areas in central districts of big cities. Most of the area cannot be used for its initial purposes. High price of renting premises in city centers make things even worse.

Reconstruction of industrial premises located in historic environment requires a specific approach. Historic building is a concentration of multiple functions and architectural forms. Therefore, the clash between the old and new is becoming even stronger in this environment along with the acceleration of historic process. Demolition is considered as a last resort when we talk about reconstruction of industrial buildings and it is not justified technically or economically.

Many foreign architectural publications show close attention to reuse of industrial buildings. They emphasize comprehensive solutions for industrial territories with objects adjacent to city centers and impact of industrial objects on architectural and spatial composition of cities.

In recent Western architectural practice, you can find more and more examples when industrial premises are used as fundamental elements of urban environment. As a rule, they are architectural spaces functioning as special purpose parks created by renovating neglected industrial or municipal zones.

In Western Europe, renovation, or restoration of urban environment to be fit for human habitation, has been actively pursued since the middle of the past century along with the beginning of the post-industrial period. Territories of former plants and factories have been converted into residential and public spaces. Industrial premises have been modified into other types of buildings, in particular, residential lofts.

It must be noted that first lofts appeared as art galleries and workshops in the 1940s of the $20^{\text {th }}$ century in Soho, an industrial district of Manhattan, where textile factories were located. Very soon, people understood the benefits of such 
premises giving them the status of prestigious residential properties and Soho turned into a bohemian district [1].

The pillars of loft, such as high walls, big windows, space that allows you to customize accommodation have been quickly implemented in new buildings construction process. Today the term loft refers to the industrial buildings converted into residential premises while preserving the elements of industrial design or new buildings in an industrial style including those that combine residential purpose with social [2].

In the 1960s, the fashion for loft crossed the ocean and began to spread from the USA to Great Britain, Germany, the Netherlands and other countries that had favorable environment for appearance and development of this concept.

The loft culture is becoming increasingly popular in Ukraine. The definition loft refers to premises of former industrial objects, factories, plants and research institutes converted and reconstructed for residential and sociocultural purposes. Most of former industrial premises are being modified into commercial and office buildings.

Refurbishment of industrial areas to clubs, galleries and art centers has become one of the recent cultural and social trends in Kyiv. On the territory of Kyiv glass package factory, now you can find 'G13 Project Studio'. It is a place for creativity, family vacation, concerts, and fun parties. The Studio consists of several zones that have been transformed, united and separated. The main halls are designed for photo and video shooting as well as for presentations, negotiations, press-conferences, seminars and much more [3].

Ukrainian popular singers Jamala and Tina Karol filmed videos for their songs there. This new location appeared to be in demand as art space, too. Thus, the congress of the Assembly of cultural life representatives, which was attended by more than one thousand people in two days, took place there. During the warm season, a summer terrace is a place for concerts, master-classes, discos.

Another example is 'Art-Zavod Platforma' located near the metro station 'Lisova'. It is the largest Ukrainian experiment in conversion of inactive industrial zones. The group of companies have completely reconstructed the trade space and a new format food market 'Bazar' appeared. In just one year, 'Art-Zavod Platforma' hosted more than 40 festivals, a large number of conferences, workshops, exhibitions, concerts, etc. 'Art-Zavod Platforma' is a unique space with permanent comfortable business and creativity cluster. It is the first project of this type in Ukraine. By developing the infrastructure of the space, the creative cluster intends to contribute to innovation development, not just in Kyiv, but also in the entire country. Human capital is the main value for them and they invite all creative and proactive people to their comfort space to collaborate, study, develop and exchange views [4].

Examples of successful industrial zones and buildings renovation can be found in Kharkiv, too: trade mall at Moskovsky Avenue, aqua park 'Jungli', shopping and entertainment center 'Frantsuzsky Bulvar', etc. Recently, in Kharkiv loft premises have begun to appear, too. The first project in this style is 'Fabrika' space.
'Fabrika' is located in the building constructed in 1933 and initially intended for crops sorting and storage. For many years, the premises of the former factory 'Soyuzsortsemovosch' had not been heated and bats became the only guests visiting them. In 1947, the building was reconstructed for the first time, and in 2015 for the second. It has been converted to a nice place for meeting friends and business partners, work and leisure, lectures, conferences and seminars [5].

The most interesting renovation project in Kharkiv is 'Art-Zavod Mekhanika' on the territory of the former plant named after V. A. Malyshev. 'Art-Zavod Mekhanika' is a transformation of the industrial territory into a cultural and creative location by preserving old appliances and constructions, keeping surroundings and a spirit of forgotten days.

All the territory is divided into four lines:

- Open space with green area, shops and bars, a summer cinema and theater stage, a petting swimming pool and a festival zone;

- Urban park, sports facilities, Extreme Park;

- Concert hall and Art Hall for exhibitions, seminars and conferences;

- Hostel to live on the territory, offices to work there, theater and art schools, IT schools, a beauty salon, clothing and food stores, creative and advertising workshops [6].

The problem of former industrial enterprises renovation is a subject of students' research work. This investigation is aimed at adopting objects of industrial architecture of the 19th-20th centuries in modern urban environment. The research has been carried out for several semesters, and the results have been used as the basis for coursework, diploma and master's theses. Investigations on historical backgrounds, functionality, planning characteristics and methods of industrial landmarks renovation methods are emphasized. Future architects, the undergraduates of Architecture and Constructions departments, together with students of Urban Construction and Environment department have been engaged in the research.

We must add several words about the uniqueness of Urban Construction and Environment specialty, which is an intermediate link between architects and constructors. Many foreign higher education institutions have it as a separate specialty that combines features of architects and constructors. Former name 'urban engineer' completely corresponds to the essence of the profession. Our students are as creative as architects are, and at the same time, they have profound knowledge and skills of construction process. That is why graduates are engaged in all the spheres of urban environment. Every year the results of Olympiads, competitions, international and local rewards confirm the high level of expertise. Participation in competitions enables students to present their works to the public.

For example, one student of Urban Construction and Environment specialty devoted her master's thesis to the methods of industrial areas renovation. The project of an old mill renovation has been presented within the master's thesis 
investigation. Located on the riverbank in the historic center of Kharkiv, the object has convenient transportation and is surrounded with architectural monuments and other tourist attractions.

The four-story dark red-brick building with white inserts and a chimney from the rear which was initially designed as the first power station in Kharkiv and later converted to the mill is neglected now (Fig. 1). You will hardly find much data on the old flour mill on the riverbank. It was a largescale enterprise but lack of funds led it to destruction. Several years ago, the process of conversion to a loft had begun, but shortage of funds stopped it and the building was put on a sale.

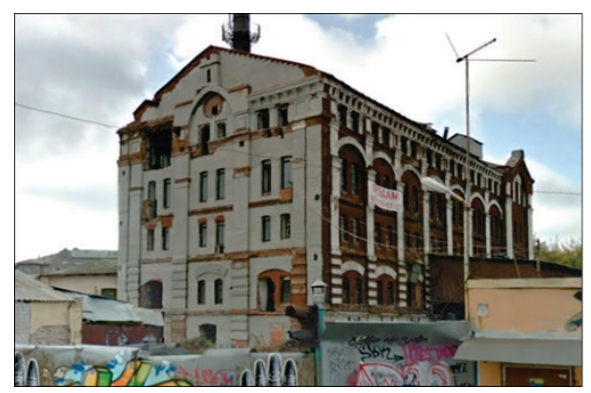

The embankment part between two bridges 'Kharkivs'ky' and 'Horbaty' had the name Dvorians'ka before the revolution, in Soviet times up to 1989 was named after Zhdanov. You can find several architectural landmarks here, such as the first private men's Lyceum named after V.F. Davydenko, which was built in 1911 by the project of architect Y.S. Tsaune. Now it is a school number 30.

Location and architectural attractiveness of the building, necessity to protect it as an industrial architecture landmark have defined such solutions as: the façade renovation,
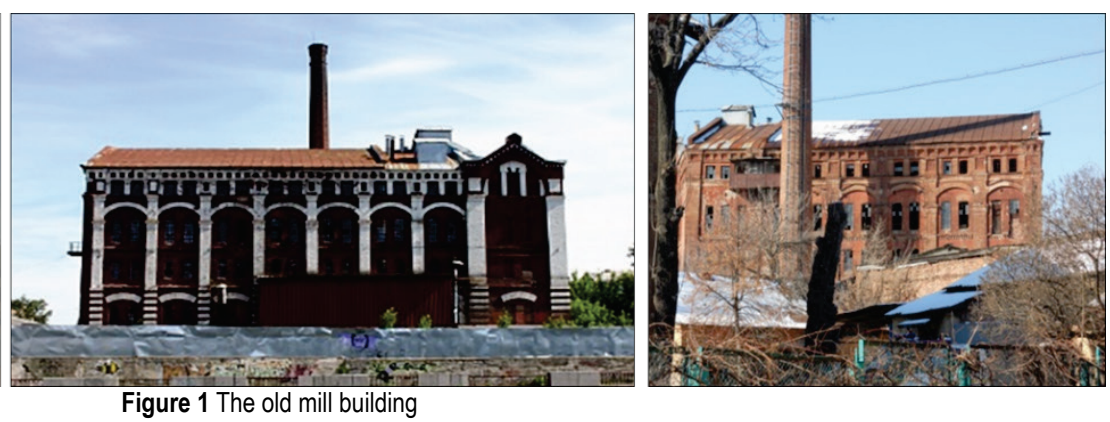

constructions physical conditions restoration, the object renovation for its second birth.

The evaluation of physical conditions has shown that the wear level in general indicators is bordering on critical $56.7 \%$. At the same time, the condition of the main constructions is satisfactory and they can be restored. Maximum preservation of the building exterior and its functionality change have been suggested in the project (Fig. 2).
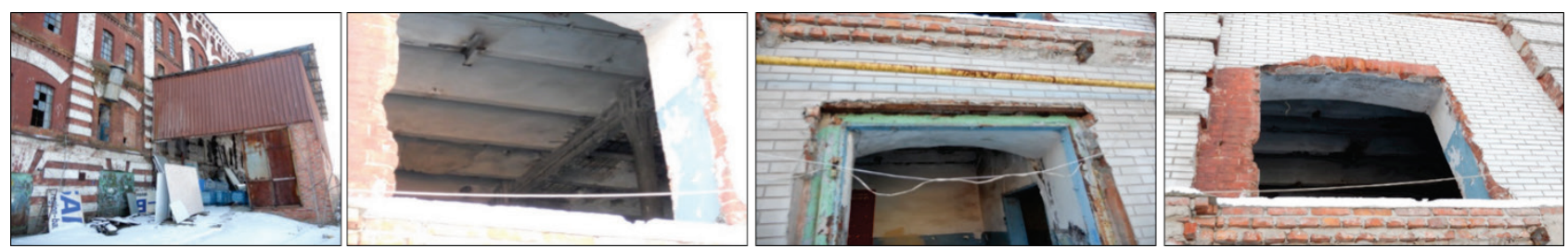

Figure 2 Physical conditions of the building
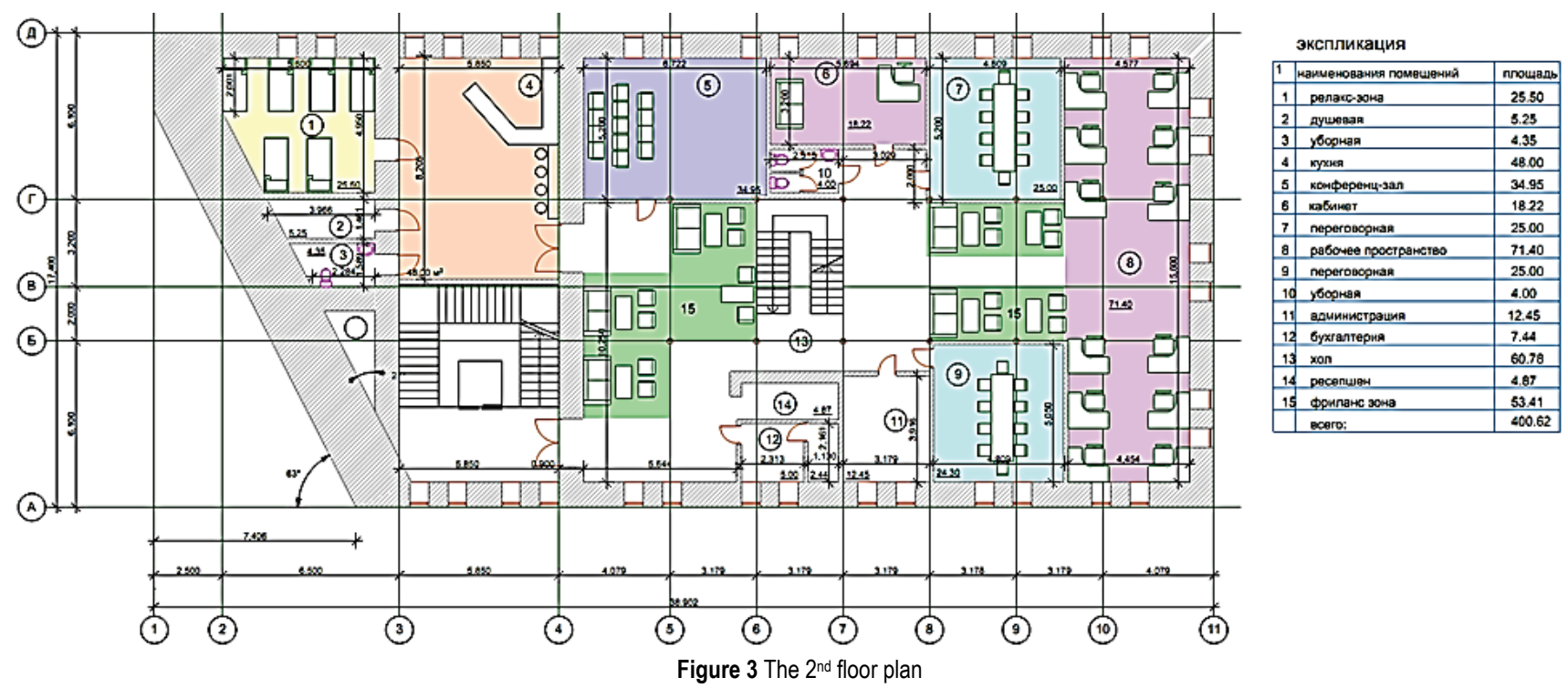

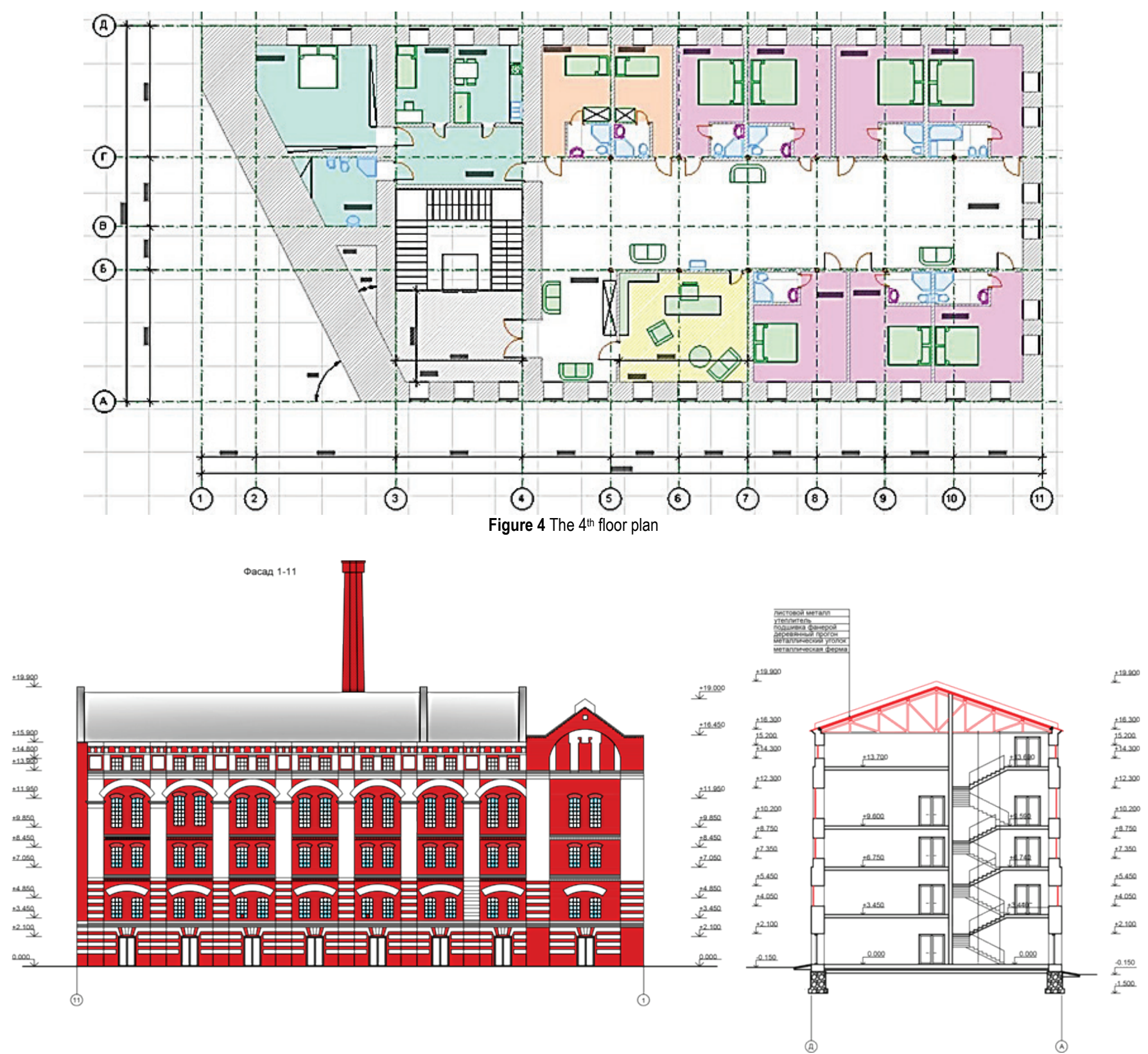

Figure 5 The Façade and cross section of the building after renovation

The old mill building is assumed to be an active cultural and social space with trade and fair zone on the first floor; open working space (coworking) on the second floor; offices on the third floor and hotel rooms on two upper floors. The territory of the embankment is supposed to be cleared and upgraded with some improvements including an access to water (Figs. 3, 4, 5).

Functionality change requires remodeling internal space of the flour mill. The process of reconstruction works has revealed that some areas of exterior walls are in poor conditions and the decision to replace them has been taken. Bricklaying of walls requires installation of temporary multilayered fixtures that can undertake load from all the preserved frames and beams (Fig. 6).

Temporary fixtures can be dismantled not earlier than in 5 days after the last bricklayer is finished.
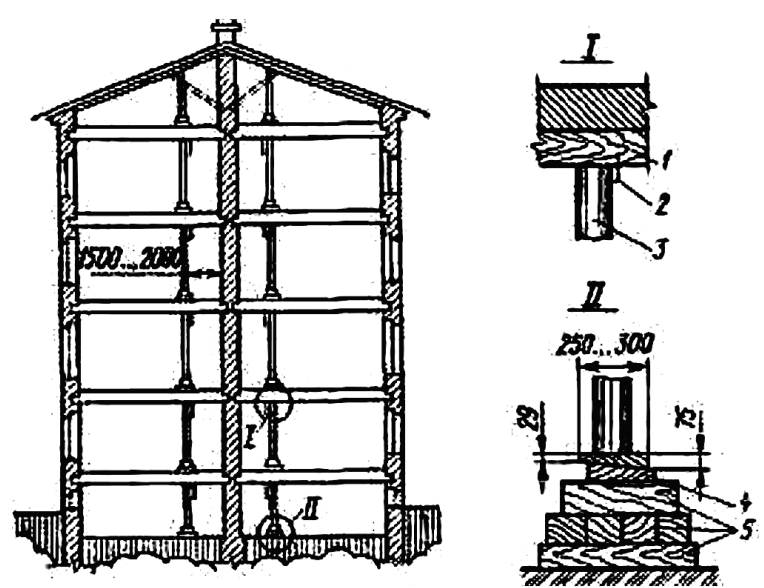

Figure 6 Installation of temporary fixtures: 1 - wooden bar; 2 - bracket; 3 - rack; 4 - wedges; 5 - supporting bars 
Before bricklaying procedure, the reasons that have caused the deformation are to be eliminated.

To release the load of the deformed wall, uploading beams are placed from both sides of the wall in the holes above it.

Firstly, the beams are installed in the weakest place of the wall. Pneumatic jackhammers are used to break the holes. Breaking the holes from the other side of the wall is to be started not earlier than in 3 days after the installation of the beam into the first hole. The length of the hole is to be $50 \mathrm{~cm}$ longer than the deformed area of the wall. Vertical gaps between beams and bricklaying are filled up with plastic cement mortar, while the gaps between the upper part of the beam and low surface of bricklaying are to be embossed. The fixtures can be dismantled and the new wall loaded on achievement $70 \%$ of the project strength [7].

The old flour mill renovation is to be accompanied with recommendations on surrounding area improvements to harmonically adopt the object into the modern urban environment and make it a bright element of the embankment architectural environment attracting tourists and proactive youth. And most importantly, the old mill building which is an industrial architecture landmark will be preserved (Fig. 8).

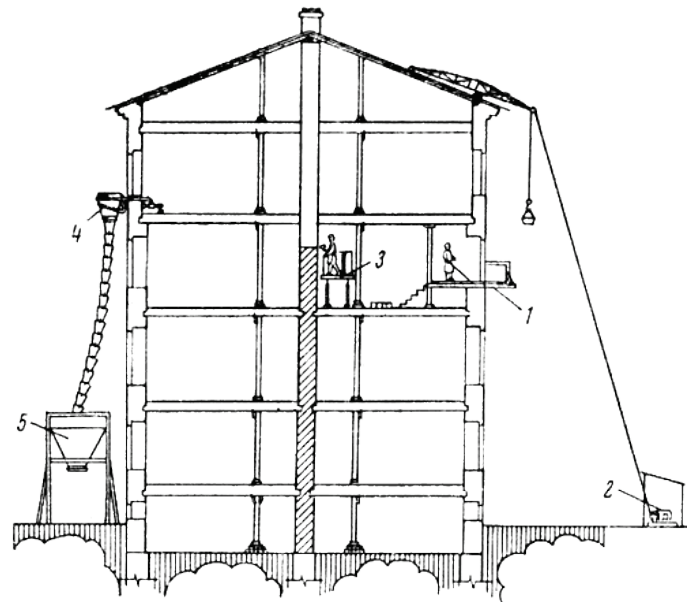

Figure 7 General scheme of works on new bricklaying of the wall with maintenance of existing frames and beams: 1 - a remote reception platform; 2 - an electrical winch; 3 - a scaffolding with inventory bars; 4 - a chain type garbage disposal; 5 waste disposal bunker [6]
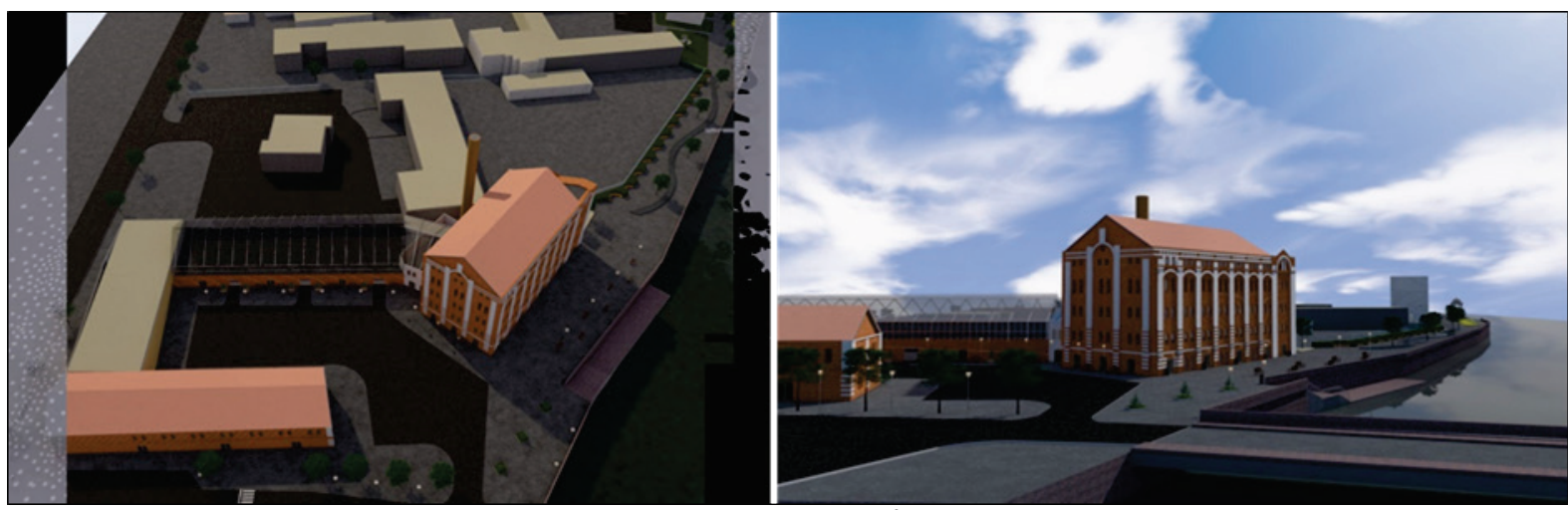

Figure 8 The embankment appearance after renovation works

The suggestions stated above will help attract investments and tourists. As a result, we will have better living conditions in this city block, it will be more visually attractive and you will feel comfortable there.

\section{CONCLUSION}

The research solves the set goal, which consisted in identifying current trends of adaptation of former industrial territories to new conditions of urban environment, at the same time improving their quality. Based on the analysis of European and American experiences, the emergence of a new type of adaptation of former industrial territories to new conditions of urban environment is improving their quality. Therefore, new social and business centers, techno parks, cultural institutions or loft residential buildings appear on the territories of plants. Experience of industrial zones reconstruction in Ukraine has not been developed enough and today focuses mainly on big cities, in particular Kyiv, Kharkiv, Dnipro.

The master's projects of the students whose specialty is urban construction and environment are presented in the research, on the basis of which new principles and techniques of reconstruction of industrial territories and industrial buildings and structures are revealed. The main goals are defined - formation of unity of unproductive industrial territories by urban territory, increase of visual attractiveness and encouragement to tourist interest, as an object of modern architecture.

\section{REFERENCES}

[1] Soho Lofts: Apartments in New York City, available online: http://www.soho-lofts.com/soho-history.html, (Accessed: 09.05.2018).

[2] Popova, O. A. (2014). Principles of loft formation in conditions restructuring of non-functioning industrial facilities: abstract arch., special: 18.00.01 - theory architecture, restoration of architectural monuments - Makeevka: Donbass National academy and Arch., p. 20

[3] G13, available online: http://www.g13.com.ua/ (Accessed: 15.04.2018).

[4] Art-zavod Platforma, http://artzavodplatforma.com/ru/news/ art-zavod-platforma-mystroim-budushchee, 09.04.2018).
(Accessed: 
[5] Fabrika.space, available online: https://bzh.life/gorod/fabrikaspace, (Accessed: 25.04.2018).

[6] Quest Pistols Show, available online: https://kh.vgorode.ua/news/dosuh_y_eda/307666 mekhanyka, (Accessed: 25.04.2018).

[7] Typical technological map, available online: http://www.amac.md/Biblioteca/data/29/02/02/05/32/216.2.pd f, (Accessed: 05.05.2018).

[8] Popova, O. A. Reorganization of industrial facilities and organization of lofts in transboundary territories, available online: https://core.ac.uk/download/pdf/11335371.pdf, (Accessed: 05.10.2018).

\section{Authors' contacts:}

Tatiana ZHYDKOVA, PhD, Associate Professor

O. M. Beketov National University of Urban Economy in Kharkiv,

Urban Construction Department,

17 Marshal Bazhanov str., 61002 Kharkiv, Ukraine

tel: (+38067-570-41-50), E-mail: tavlz@ukr.net

Svetlana CHEPURNA, PhD, Senior Lecturer Associate

O. M. Beketov National University of Urban Economy in Kharkiv,

Urban Construction Department,

17 Marshal Bazhanov str., 61002 Kharkiv, Ukraine

tel: (+38093-671-84-36), E-mail: s.chepurna0274@gmail.com

Olga POPOVA, PhD, Associate Professor

O. M. Beketov National University of Urban Economy in Kharkiv,

Architecture of buildings and Architectural Environment Design Department,

17 Marshal Bazhanov str., 61002 Kharkiv, Ukraine

tel: (+38099-668-00-02), E-mail: olya133113@gmail.com

Petr CHABANENKO, PhD, Professor

Odessa State Academy of Civil Engineering and Architecture,

Urban Construction and Economy Department,

28 Staroportofrankivs'ka Str., Odesa 65020, Ukraine

tel: (+38067-482-69-03), E-mail: ogasagsh@ukr.net 